\title{
PEMBERDAYAAN NILAI-NILAI MASYARAKAT LOKAL SEBAGAI MODAL PEMBANGUNAN DEMOKRASI
}

\author{
Miswardi \\ IAIN Bukittinggi,miswardi@iainbukittinggi.ac.id
}

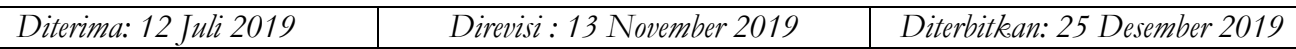

\begin{abstract}
The demand for a democratic system of government in Indonesia is not only the demands of society but also constitutional demands. Therefore, regional autonomy is expected to be able to provide answers to both needs. Because the essence of local independence itself is a tangible form of the practice of democracy in society, in the way of giving autonomy to the region to advance its society democratically in various aspects of life, politics, social economy and culture, to answer the challenges in the era of globalization. Community involvement by empowering local community values is one surefire strategy in the process of democratization. Besides, bureaucratic reform is a necessity; therefore, a combination of allowing the benefits of local communities with the government bureaucracy system is an appropriate strategy for accelerating democratic development.
\end{abstract}

Keywords: Islamic Law, Criminal Law, Development Law Theory.

\begin{abstract}
Abstrak
Tuntutan terhadap sistem pemerintahan yang demokratis di Indonesia bukan hanya tuntutan masyarakat semata akan tetapi merupakan tuntutan konstitusi. Oleh karena itu otonomi daerah sangat diharapkan mampu memberikan jawaban atas kedua tuntutan itu. Karena hakikat otonomi daerah itu sendiri adalah bentuk nyata daripada praktik demokrasi di dalam masyarakat dalam bentuk pemberian kemandirian kepada daerah untuk memajukan masyarakatnya secara demokratis dalam berbagai aspek kehidupan, politik, ekonomi sosial dan budaya, untuk menjawab tantangan di era globalisasi. Penglibatan masyarakat dengan pemberdayaan nilai-nilai masyarat lokal merupakan salah satu stategi jitu dalam proses demokratisasi. Selain itu reformasi birokrasi merupakan keniscayaan, oleh karena itu perpaduan antara pemberdayaan nilai-nilai masyarakat lokal dengan sistem birokrasi pemerintaban merupkan strategi tepat untuk, percepatan pembangunan demokrasi.
\end{abstract}

Kata kunci : Nilai-nilai Masyarakat Lokal, Birokrasi dan Demokrasi.

\section{PENDAHULUAN}

"Democracy is not herritag, but democrac $y$ is learned" demokrasi tidak diturunkan melalui kelahiran tetapi dicerna melalui proses belajar. Demokrasi adalah sebuah konsep yang lahir dari tradisi pemikiran Yunani sebagai antitesis dari konsep otoriter Romawi yang mulai dikembangkan sejak abad ke 6 SM sampai abad ke 4 M. Sesuai dengan kondisi pada awal mula berkembangnya konsep demokrasi

${ }^{1}$ Jordi Feu et al., "Democracy and Education: A Theoretical Proposal for the Analysis of Democratic Practices in Schools," Studies in Philosophy and Education 36, no. 6 (2017): 647-61, doi:10.1007/s11217-017-95707. dimana masyarakat yang masih sederhana hak rakyat untuk membuat keputusan politik dijalankan secara langsung oleh seluruh warga negara berdasarkan prosedur mayoritas yang disebut dengan konsep demokrasi langsung (direct domocration). Praktek demokrasi langsung itu tidak bertahan lama disebabkan terjadinya perubahan dalam sistem kemasyarakatan Yunani pada masa itu terutama disebabkan pengaruh kehidupan keagamaan yang berpusat pada Paus dan pejabat Agama dengan kehidupan politik yang ditandai dengan perebutan kekuasaan dikalangan bangsawan 
yang melahirkan kembali sistem kemasyarakatan feodal. ${ }^{2}$

Tarik ulur praktek kehidupan masyarakat feodal dan demokrasi berlangsung dalam masa yang cukup lama dimana kedua konsep tersebut saling mengembangkan pengaruh terutama dikawasan Eropa ${ }^{3}$ yang pada umumnya dikuasai sistem feodal.

Praktek demokrasi bangkit kembali di Eeropa menjelang abad pertengahan ditandai dengan lahirnya magna charta ${ }^{4}$ di Inggris sebagai suatu piagam yang memuat perjanjian antara rakyat kaum bangsawan dengan Raja, dalam magna charta tersebut ditegaskan bahwa raja mengakui dan menjamin beberapa hak rakyat terutama yang berkaitan dengan hak dasar (asasi) yakni pertama: adanya pembatasan kekuasaan raja, kedua, dalam menjalankan kekuasaannya raja harus menghormati hak asasi manusia (rakyat). ${ }^{5}$

\footnotetext{
2 Jason Gainous, Jason P. Abbott, and Kevin M. Wagner, "Traditional Versus Internet Media in a Restricted Information Environment: How Trust in the Medium Matters," Political Behavior 41, no. 2 (2019): 401-22, doi:10.1007/s11109-018-9456-6.

3 Dalam sejarah perkembangan sistem pemerintahan demokrasi Yunani dan sistem pemerintahan Feodal Romawi masing-masing mengembangkan pengaruh dikawasan Eropah, pengaruh Yunani lebih berkembang dikawasan Eeropah selatan sedangkan pengaruh Romawi dengan sistem pemerintahan feodalnya lebih berkembang di kawasan Eropah Utara (kawasan dataran tinggi) yang pada mulanya menumbuhkan penguasa tanah (land lord) yang kemudian berkembang menjadi negara kerajaan. Sedangkan kawasan Eropa Selatan merupakan kawasan pesisisir dimana penduduknya hiterogen yang terdiri dari para pedagang dari berbagai daerah sehingga kepentingan mereka pada dasarnya adalah untuk berdagang tidak ada kepentingan untuk menguasai kawasan, sehingga sistem demokrasi lebih cenderung untuk berkembang dibandingkan dengan dikawasan Eropah utara.

${ }^{4}$ Magna Charta, merupakan tonggak awal dari lahirnya konstitusi di negara-negara dunia dewasa ini, karena kelahiran magna charta adalah sebagai respons dari raja atas tuntutan Rakyat terhadap feodalisme kekuasaan raja. Oleh karena itu inti dari isi magna Charta adalah pembatasan kekuasaan raja dengan perlindungan hak asasi manusia.

${ }^{5}$ Ibid.
}

Momentum lain yang menandai lahirnya kembali demokrasi di Eropa adalah gerakan pencerahan (renaissance) dan reformasi. Gerakan pencerahan Barat merupakan buah dari kontak Eropa dengan dunia Islam ketika itu sedang berada pada puncak kejayaan peradaban dan Ilmu pengetahuan perkembangan ilmu pengetahuan ini memberikan dampak besar terhadap tuntutan kembali munculnya sistem demokrasi di masyarakat barat. Ini membuktikan bahwa sesungguhnya demokrasi itu bukan sesuatu yang turun begitu saja dari langit akan tetapi memerlukan pembelajaran untuk memberikan kesadaran akan perlunya demokrasi.

Walaupun sebenarnya demokrasi sebagai nilai-nilai dasar universal umat manusia, akan tetapi tidak begitu saja nilai tersebut dapat diwujudkan dalam praktek bernegara, karena banyak faktor yang menghambat tumbuh berkembangnya nilai demokrasi dalam masyarakat, terjadi gelombang pasang surut demokrasi dibanyak negara di Indonesia misalnya walaupun di dalam konstitusi (UUD 1945) secara tegas dinyatakan bahwa Indonesia adalah negara hukum yang berdasarkan demokrasi, akan tetapi juga tidak serta merta konsep demokrasi dapat berjalan di Indonesia, misalnya saja pada masa orde lama dan orde baru sistem pemerintahan Indonesia sangat jauh dari nilainilai demokrasi itu sendiri bahkan lebih cendrung nilai otoriternya.

Kondisi di banyak negara seperti ini, menunjukkan bahwa pembangunan demokrasi tidak cukup hanya dengan modal keinginan negara saja akan tetapi banyak faktor yang harus dilibatkan terutama nilai-nilai kearifan lokal (local wisdom) karena demokrasi pada dasarnya berakar pada masyarakat dimana demokrasi itu akan ditumbuhkan.

Di negara yang bercita-cita untuk mensejahterakan masyarakat (warfare state), dengan konsep demokrasi sebagai landasan 
pembangunan bangsa, ${ }^{6}$ partisipasi masyarakat dalam berbagai aspek pembangunan mutlak diberikan, karena tanpa adanya partisipasi masyarakat pembangunan yang dilakukan oleh negara hanyalah menjadikan masyarakat sebagai objek, sehingga tidak dapat disalahkan apabila masyarakat merasa "tidak memiliki dan tidak bertanggung jawab" terhadap pembangunan yang telah dilakukan oleh pemerintah. Oleh karena itu dalam konsep pembangunan di dalam negara demokrasi, penempatan masyarakat sebagai objek pembangunan mutlak dilakukan sehingga masyarakat akan dapat berperan secara aktif mulai dari perencanaan, pelaksanaan, hingga monitoring dan evaluasi pembangunan, terlebih apabila akan melakukan pembangunan dengan semangat lokalitas, masyarakat lokal menjadi bahagian yang paling memahami keadaan daerahnya tentu akan mampu memberikan masukan yang sangat berharga. Dalam teori ilmu sosial dikatakan bahwa nilai yang tumbuh dan berkembang di tengah masyarakat merupakan modal sosial (social capital) yang sangat berharga yang akan dapat dimanfaatkan untuk mensejahterakan masyarakt lokal tersebut, bahkan masyarakat lokal dengan pengalaman dan pemahamannya menjadi modal yang sangat besar bagi negara dalam melaksanakan pembangunan,karena masyarat lokal-lah yang paling mengetahui segala permasalahan yang dihadapi serta juga potensi yang dimiliki oleh daerahnya, bahkan juga mereka akan memiliki pengetahuan lokal untuk menyelesaikan permasalahan yang dihadapi tersebut.

Oleh karena itu dalam konteks otonomi daerah penerapan dan pelaksanaan pembangunan harus melibatkan peran serta masyarakat, pengambilan keputusan tidak lagi dilaksanakan secara terpusat (top down) karena

${ }^{6}$ Di dalam penjelasan Pasal 1 UUD 1945 secara tegas dinyatakan bahwa Indonesia adalah negara hukum yang berdasarkan demokrasi dengan tujuan untuk mensejahterakan masyarakat. model seperti ini tidak aakan mampu merefleksikan aspirasi masyarakat yang justru akan menjadi tujuan dari pembangunan itu sendiri.

Midgley ${ }^{7}$ menyatakan bahwa partisipasi bukan hanya sekedar salah satu dari tujuan pembangunan sosial tetapi merupakan bagian yang tidak dapat dipisahkan dalam proses pembangunan sosial, partisipasi masyarakat berarti perwujudan eksistrensi manusia seutuhnya. ${ }^{8}$ Tuntutan akan partisiasi masyarakat semakin meningkat seiring dengan kesadaran akan hak dan kewajiban negara, pengalaman kegagalan pembangunan perspektif modernisasi yang mengabaikan partisiasi publik menjadi mementum yang berharga dalam tuntutan peningkatan partisipasi warga masyarakat, tuntutan ini semakin kuat seiring kuatnya negara menekan kebebasan masyarakat.

Partisipasi publik dalam bentuk munculnya inisiatif lokal merupakan suatu hak penting untuk menumbuhkan inisiatif lokal merupakan suatu hal penting untuk menumbuhkan iklim demokratisasi pada tingkat lokal. Dengan cara ini dapat diharapkan bahwa setiap keputusan publik betul-betul berpihak kepada publik, dengan demikian semakin kuatnya inisiatif lokal kecendrungan untuk terjadinya proses alienasi dan tidak berdayanya individu dapat dikurangi. Dengan mendorong munculnya inisiatif lokal yang optimal maka proses pemaknaan dan identifikasi individu atas keberdayaannnya akan terwujud, sehingga pemaknaan dan pemenuhan identitas personal tidak lagi dikuasasi oleh struktur-struktur besar, namun

7 James Midgley, Community Partisipation, socialsosial develpoment and the state, (London: Methium, 1996), 77

8 Coralie Bryant \& Louise G White dalam Manajemen Pembangunan untuk negara berkembang, diterjemahkan oleh Rusyanto L Simatupang, Jakarta: LP3 ES ,1987), 268-276 mengingatkan pula agar konsep partisipasi tidak dipersempit hanya pada aspek penerimaan manfaat belaka karena akan mengubah pengertian umum partisipasi. 
lebih terwujud dalam lingkungan publik sehingg kehidupan masyarakat umum tidak lagi dalam posisi terpinggirkan serta makna personal individu akan lebih kuat.

Sistem politik Indonesia yang cenderung otoriter selama masa orde baru berdampak pada hilangnya kreativitas dan inovasi masyarakat lokal dalam berbagai aspek kehidupan, baik aspek sosial maupun aspek kehidupan bernegara, karena pola pemerintahan orde baru dengan landasan stabilitas nasional pola pembangunan cendrung top down, yang tidak memberikan kebebasan kepada masyarakat lokal untuk berinovasi sesuai dengan kebutuhan lokal.

Pola seperti ini melahirkan sikap generasi bangsa yang apatis, keengganan dan bahkan rasa ketakutan masyarakat untuk berpartisipasi dalam berbagai aspek kehidupan tersebut di atas. Lebih jauh hal ini juga berdampak kepada tidak berfungsinya lembaga-lembaga masyarakat lokal sebagaimana mestinya, dan ketergantungan masyarakat kepada pemerintah semakin tinggi, kondisi seperti ini semakin menjauhkan dari proses demokratisasi. Dalam konsep demokratisasi partisipasi masyarakat yang diharapkan datang dari bawah justru terbalik menjadi mobilisasi pembangunan dari atas.

\section{OTONOMI DAERAH DEMOKRATISASI}

Litvaack \& Seddon, ${ }^{9}$ desentralisasi atau otonomi daerah dimaknai sebagai "the transefer of outhority responsibility for public from the central government to sub ordinate or quasi indefendent government organization, or the privat sector". Pada sisi lain Rondinelli ${ }^{10}$ menekankan desentralisasi atau otonomi daerah itu sebagai "transfer of

9 Larry Diamond, "Rethinking Civil Society: Toward Democratic Consolidation," Journal of Democracy 5, no. 3 (1994): 4-17.

${ }^{10}$ Ibid. 61 political power". Sedangkan Priyatmoko, MA. ${ }^{11}$ Menyatakan desentralisasi dengan wujud otonomi daerah pada dasarnya menyangkut pengalihan kekuasaan dan sumber daya dari pusat ke daerah.

Dalam pembangunan demokrasi suatu negara tidak bisa terlepas dari beberapa elemen penting seperti politik dan hukum, perpaduan antara dua elemen tersebut merupakan suatu yang sangat penting karena suatu negara yang didominasi oleh kekuasaan politik akan cenderung menjadi feodal, sedangkan apabila suatu negara hanya didominasi oleh kekuasaan hukum tanpa ada kekuasaan politik akan lemah.

Oleh karena itu untuk membangun demokratisasi dalam suatu negara perpaduan kekuasaan hukum dengan kekuasaan politik merupakan suatu kemestian dengan posisi hukum sebagai panglima yang mampu mengendalikan dan mengarahkan politik, seperti yang telah menjadi prinsip dalam negara hukum Indonesia. Pemerintah (dalam hal ini juga termasuk pemerintah daerah) sebagai pemegang kewenangan public (performing public authority), yang didapat berdasarkan pelimpahan kewenangan oleh rakyat diharapkan mampu merespon nilai-nilai yang tumbuh dan berkembang ditengah masyarakat lokal dan menempatkan sebagai modal sosial (sosial capital).

Menurut Leumieux, ${ }^{12}$ otonomi daerah sebagai suatu kebebasan bagi daerah untuk mengambil keputusan sendiri baik dalam bidang politik maupun dalam bidang administrasi dengan tetap menghormati peraturan perundang-undangan. Sedangkan

11 Priyatmoko, "Peningkatan Profesionalisme Eksekutif Dan Implementasi Otonomi Daerah", Makalah dalam Workshop Desentralisasi, Demokrasi dan Akuntabilitas Daerah oleh Asosiasi Ilmu Politik Indonesia (AIPI) dan Parthnership for Governance Reform Indonesia, (Semarang: 25 - 27 Maret 2002), 1.

${ }^{12}$ Leumeux, dikutip oleh Siti Zuhro, Pemerintan Lokal dan otonomi daerah di Indonesia, Thailand dan Pakistan, Jakarta: PPW LIPI, 1998), 5. 
oleh Kjellberg ${ }^{13}$ otonomi dimaknai sebagai Local self government yang terdapat sets of values, such as. Liberty or outonomy, democration or participation and efficiency" pertama, otonomi sebagai nilai utama dari teori lokal self government, dimaknai sebagai konsep freedom from something kepada freedom to do something, atau local authonomy become an instrument for the realization of communal interest. Kedua, partisipasi atau demokrasi bermakna untuk memperkuat demokratisasi dalam masyarakat supaya adanya partisipasi aktif masyarakat itu senidiri.

David Held ${ }^{14}$ berpendapat bahwa otonomi berarti sebagai kapasitas manusia untuk memahami kesadaran dirinya, merefleksikan dirinya dan menentukan nasibnya sendiri dengan prinsip-prinsip sebagai berikut: a) masyarakat seharusnya merasa nyaman dengan hak-hak yang setara dan sejalan dengan itu. b) kewajiban yang setara pula di dalam kehususan kerangka kerja politik yang memberikan sekaligus membatasi kesempatan yang disediakan untuk mereka. Prinsip-prinsip ini berarti mereka bebas dan sederajat menentukan kehidupan mereka sendiri selama mereka tidak memasuki hak orang lain. Prinsip otonomi menggambarkan secara mendasar dua gagasan dasar :

1. Ide bahwa rakyat seharusnya berhak untuk menentukan sendiri nasibnya.

2. Gagasan tentang pemerintahan demokrasi harus terbatas sebagai pemerintah yang menegakkan susunan kekuasaan yang mengikuti undang-undang.

Beranjak dari pemikiran di atas, terlihat betapa sangat pentingnya peranan masyarakat dalam konsep pemerintahan daerah, sehingga nilai-nilai masyarakat lokal dalam penyelenggaraan pemerintahan daerah merupakan aspek penentu untuk mewujudkan

${ }^{13}$ Francesco Kjellberg, "The Changging Values of Lokal Governement”, Annals AAPPS, (540 July 1995), 40-50.

${ }^{14}$ David Held, "Menggagas Ulang Demokrasi", Jurnal Ilmu dan Kebudayaan UNISLA, (No. 36/XX/IV/1999), 75. makna otonomi daerah, dengan kata lain otonomi sebagai prasyarat dari demokratisasi, karena otonomi juga sebagai wadah bagi masyarakat lokal untuk merefleksikan kesadaran diri untuk menentukan nasibnya sendiri, atau untuk bertindak sebagai pencipta kehidupan sendiri baik dalam dunia politik maupun dalam kehidupan pribadi tanpa ketergantungan dengan pihak lain, yang dalam kontek pemerintahan masyarakat lokal tidak tergantung kepada pemerintah pusat untuk mengekspresikan diri, memberdayakan nilainilai lokal untuk mewujudkan kesejahteraan sendiri.

Menurut Undang-Undang yang mengatur tentang Otonomi Daerah yakni Undang-Undang Nomor 22 tahun 1999 tentang Pemerintahan Daerah yang diganti dengan Undang-Undang nomor 32 tahun 2004 tentang Pemerintahan Daerah dan diubah kembali menjadi Undang Undang Nomor 23 Tahun 2014 tentang Pemerintahan Daerah, dimana otonomi daerah dimaksudkan sebagai desentralisasi kekuasaan pemerintah yang selama masa orde baru tersentral pada pemerintahan pusat, dimana daerah hanya menerima segala kebijakan pemerintah pusat baik dalam bidang ekonomi, sosial maupun politik. Praktek seperti itu kemudian disadari tidak memberikan banyak makna bagi kehidupan masyarakat, terutama masyarakat lokal karena masyarakat lokal tidak diberikanb kesempatan untuk merefleksikan nilai-nilai yang mereka miliki sendiri, tetapi justru sebaliknya masyarakat lokal hanya disuguhi dengan nilai-nilai yang telah diformat sedemikian rupa oleh pemerintah pusat, masyarakat lokal sebagai subjek dalam pembangunan demokrasi tidak dilibatkan dalam pengambilan keputusan penting, sehingga tidak heran manakala rakyat sendiri merasa asing dengan kebijakan yang diambil oleh pemerintah. Pengalaman seperti itu kemudian sangat memberikan kesan negatif dalam pembangunan demokrasi. Atas 
kesadaran dengan kondisi seperti demikian itu maka dengan semangat undang - undang otonomi daerah dimaksudkan untuk memberikan kebebasan kepada masyarakat lokal untuk berekspresi dengan nilai-nilai lokal, karena sebagaimana dikatakan diatas, bahwa demokrasi itu bukan turun dari atas, akan tetapi demokrasi itu lahir dari bawah (masyarakat).

Hakekat demokrasi sesungguhnya adalah upaya untuk menempatkan masyarakat sebagai subjek dari pembangunan, karena masyarakat yang tahu pembangunan seperti apa yang mereka kehendaki dan pembangunan seperti apa yang mampu membuat mereka menjadi sejahtera. Pembangunan yang tidak melibatkan masyarakat hanyalah menjadikan masyarakat sebagai objek dalam upaya demokratisasi. Penempatan masyarakat sebagai subjek pembangunan merupakan suatu kemestian sehingga masyarakat akan mampu berperan serta secara aktif mulai dari perencanaan, pelaksanaan hingga pengawasan dan penilaian pembangunan, oleh karenanya pembangunan sudah seharusnya memahami dan merespons semangat masyarakat lokal, karena masyarakat lokal menjadi bahagian yang paling memahami keadaan daerahnya. Pada sisi lain pemahaman dan pengalaman masyarakat lokal terhadap nilai-nilainya menjadikan sebagai modal pembangunan yang sangat besar (sosial capital).

Proses demokratisasi tidak mungkin akan terjadi manakala penerapan dan pelaksanaan pembangunan tidak melibatkan masyarakat lokal sebagai pemilik kedaulatan, karena model pembangunan sentralisasi tidak akan mampu menterjemahkan aspirasi masyarakat yang justru menjadi tujuan pembangunan itu sendiri, karena sebagaimana dikatakan oleh Midgley ${ }^{15}$ bahwa pelibatan masyarakat dalam pembangunan bukan hanaya sekedar salah satu dari tujuan pembangunan

\footnotetext{
15 James Midgley, Cummunity Partisipation, ..., 77.
}

sosial tetapi merupakan bagian yang menyatu dalam proses pembangunan sosial.

Penglibatan masyarakat dalam proses pembangunan disegala bidang dalam konteks demokratisasi merupakan perwujudan manusia seutuhnya atau dengan kata lain memanusiakan manusia. ${ }^{16}$ Dewasa ini seiring dengan meningkatnya kesadaran masyarakat akan hak dan kewajiban negara, tuntutan penglibatan masyarakat dalam berbagai aspek pembangunan semakin meningkat, hal ini juga didasari dengan pengalaman kegagalan pembangunan pada masa orde baru yang mengabaikan penglibatan masyarakat dan hanya menjadikan masyarakat sebagai objek pembangunan dan medernisasi sebagai slogan yang selalu dijunjung.

Dalam teori sosial tuntutan penglibatan partisipasi masyarakat dengan nilai-nilai lokalnya dalam proses pembangunan semakin meningkat, manakala tekanan negara semakin tinggi terhadap kebebasan masyarakat. Perlawanan terhadap modernisasi yang menjauhkan pembangunan dari partisipasi masyarakat tersebut terjadi dimanamana terutama dinegara berkembang yang kemudian melahirkan apa yang disebut dengan post modernisme, yang tidak hanya sekedar melakukan perlawanan terhadap modernisme yang mengabaikan nilai masyarakat lokal, akan tetapi juga meberikan solusi dan model pembangunan yang dirasa lebih tepat dalam konteks demokratisasi. ${ }^{17}$

${ }^{16}$ Coralie Bryant \& Louise G. White, Manajemen Pembangunban Negara Berkembang, Penerjemah: Rusyanto L. Simatupang, (Jakarta: LP3ES, 1987). 268 - 276. Mengingatkan pula agar konsep partisipasi tidak dipersempit hanya pada aspek penerimaan manfaat belaka, karena akan mengubah pengertian umum partisipasi. Aspek penerimaan manfaat akan merupakan pelengkap dari cakupan pada proses perencanaan dan pelaksanaan sehingga membawa manfaat yang lebih besaar bagi masyarakat awam.

${ }^{17}$ Naeni Amanulloh, "Demokratisasi Desa :," in Kementerian Desa, Pembangunan Daerah Tertinggal, Dan Transmigrasi Republik Indonesia, 3rd ed. (Jakarta, 2015), 147. 
Modernisme yang selama ini menjadi slogan pembangunan dibanyak negara berkembang dianggap tidak mampu mewujudkan hakekat pembangunan yang sesungguhnya dan bahkan sebaliknya pembangunan hanya menumbuhkan kesengsaraan masyartakat pada satu sisi, misalnya pembangunan justru menjauhkan masyarakat dengan nilai-nilai lokalnya dan masyarakat tercabut dari akar budaya dan melahirkan suatu budaya baru (new cultural) yang sangat jauh dari nilai-nilai kehidupan sosialnya.

Model pembangunan ini merupakan alternatif yang dirasa akan mampu merespon nilai-nilai sosial masyarakat lokal dan mendorong partisipasi masyarakat dalam berbagai aspek pembangunan, karena konsep post modernisme menawarkan tiga aspek yaitu 1) menempatkan masyarakat lokal sebagai agen pembangunan itu sendiri, 2) menjadikan pembangunan partisipatif sebagai suatu metode, 3) arah dan tujuan pembangunan ditetapkan oleh masyarakat itu sendiri, dimana peran negara hanya sebagai fasilitator yang membantu dan mengarahkan. ${ }^{18}$

Berkembangnya paradigm post
modernisme dewasa ini dibanyak negara dipicu oleh pengalaman kegagalan penerapan paradigm modernisme yang hanya menekankan pada pertumbuhan ekonomi semata dengan mengabaikan pertumbuhan sektor lainnya seperti sektor pertumbuhan siumber daya manusia, sektor sosial budaya, hal ini ditandai dengan pengalaman buruk krisis ekonomi tahun 1999 banyak Negara yang menerapkan paradigm modernisme dalam pembangunannya mengalami kolaps. Alternatif pembangunan dengan paradigm post modernisme mengusung slogan "things globality act lokality" dengan suatu

${ }^{18}$ Daniel A. Sangian, Salmin Dengo, and Jericho D. Pombengi, "Summary for Policymakers," in Climate Change 2013 - The Physical Science Basis, ed. Intergovernmental Panel on Climate Change, vol. 53 (Cambridge: Cambridge University Press, 2013), 1-30, doi:10.1017/CBO9781107415324.004. kepastian terjadinya keberagaman kepentingan pembangunan karena dihadapkan pada permasalahan lokal yang berbeda, karena model paradigma alternatif ini pembangunan berupaya untuk menyesuaikan dengan kondisi lokal yang ada.

Penglibatan masyarakat dalam format memberikan kesempatan yang luas dalam mengajukan inbisiatif dan inovatif merupakan sesuatu yang sudah semestinya dilakukan dalam proses demokratisasi pada tingkat lokal, karena dengan cara seperti ini diyakini bahwa setiap keputusan atau kebijakan publik betulbetul berpihak kepada masyarakat, terutama masyarakat yang akan menjadi objek kebijakan tersebut, sehingga tingkat respons masyarakat terhadap keputusan atau kebijakan tersebut semakin tinggi, yang pada akhirnya akan menumbuhkan tingkat kepercayaan (trust) masyarakat terhadap pemerintah juga semakin tinggi dan posisi masyarakat tidak lagi terpinggirkan.

\section{MASYARAKAT LOKAL SEBAGAI BASIS DEMOKRATISASI}

Pengembangan masyarakat (community depelovment) merupakan upaya terpenting yang perlu menjadi perhatian dalam proses transformasi sosial sebagai bagian ikhtiar meningkatkan kesejahteraan masyarakat melalui strategi prakarsa, aspirasi, keperluan dan kemampuan masyarakat. Pengalaman dibanyak negara yang sistem pemerintahannya cendrung feodal, program pembangunan dirancang dari luar masyarakat atau dari pusat pemerintahan, sehingga perencanaan kurang memperhatikan potensi dan keperluan masyarakat lokal, tidak mengherankan manakala inisiatif masyarakat sulit untuk dikembangkan sehingga masyarakat lokal sangat terggantung pada kekuatan dan kekuasaan luar.

$$
\text { Dampak lanjutan partisipasi }
$$
masyarakat lokal sangat rendah terhadap program pembangunan yang dilaksanakan oleh 
pemerintah (pusat) karena masyarakat lokal tidak tahu apa tujuan dari program tersebut. Dalam kondisi seperti demikian sustainebelity suatu program sangat rapuh karena sikap memiliki dan tanggung jawab untuk meneruskan apa yang telah dilakukan oleh pemerintah sangat rendah. Kondisi seperti ini sangat tidak menguntungkan dalam proses demokratisasi. ${ }^{19}$

Dampak dari kondisi seperti ini seiring dengan tumbuhnya semangat demokratisasi di Indonesia dewasa ini maka muncul paradigma baru dalam masyarakat, yang menekankan bahwa pengembangan demokratisasi perlu memperkuat kemampuan masyarakat lokal dengan menumbuhkan partisipasi, inisiatif dan kepemimpinan lokal. Untuk mencapai itu semua pemberdayaan masyarakat dan memperkuat institusi lokal sangat diperlukan, dengan memberikan kewenangan dan otoritas kepada masyarakat lokal untuk merencanakan dan menentukan pilihan-pilihan dan secara aktif terlibat dalam perencanaan, pelaksanaan, pengendalian hingga pemanfaatan hasil, untuk itu juga diperlukan partisipasi masyarakat secara nyata.

Peluang demokratisasi itu pasca orde baru sangat terbuka lebar diantaranya ditandai dengan perubahan paradigma sistem pemerintan dari sistem sentraliasi kepada sistem desentralisasi dengan otonomi daerah, dengan diberlakukkannya undang-undang no 32/2004 tentang Pemerintahan Daerah yang diubah dengan undang-undang nomor 22 tahun 1999 tentang Pemerintahan Daerah. Hakekat kedua undang-undang tersebut adalah upaya pemberdayaan potensi lokal dalam berbagai aspek, termasuk kewenangan politik daerah untuk memberdayakan segala potensi yang dimiliki daerah baik potensi

19 Heru Nugroho, "Demokrasi Dan Demokratisasi: Sebuah Kerangka Konseptual Untuk Memahami Dinamika Sosial-Politik Di Indonesia," Jurnal Pemikiran Sosiologi 1, no. 1 (December 2015): 1, doi:10.22146/jps.v1i1.23419. sumber daya alam, sumber daya manusia, maupun potensi sosial ekonomi dengan memberdayakan institusi-instusi atau lembaga adat masyarakat.

Pemberdayaan inisiatif lokal dalam proses pembangunan merupakan upaya untuk melibatkan masyarakat dalam memberikan sumbangan pemikiran, ide perencanaan bahkan sampai pada sumbangan pendanaan, pemeliharaan dan penyelesaian permasalahan yang terjadi, dengan demikian pelibatan masyarakat lokal dalam pembangunan merupakan perwujudan dari semboyan demokrasi dari rakyat, oleh rakyat dan untuk rakyat.

Dalam teori ilmu sosial dapat diketahui ada dua pendekatan yang dapat dilakukan untuk membangun inisiatif lokal yaitu pendekatan personal dan pendekatan kemasyarakatan. ${ }^{20}$ Dalam pendekatan personal dapat berupa upaya untuk menumbuhkan persaingan individu dalam kaitannya dengan kegiatan tertentu yang dapat diwujudkan dalam bentuk tanggungjawab sosial dengan

20 D Osborne dan $\mathrm{T}$ Gaebler, Reinventing Government: How the Entrepreneurial Spirit is Transforming the Public Sector, A William Patrick Book (Addison-Wesley Publishing Company, 1992), 65-70 menyatakan partisipasi publik tidak saja dalam hal pembangunan akan tetapi juga dalam hal pelayanan publik juga akan memberikan manfaat yang sangat besar. Dari ungkapan kedua pakar tersebut dapat diambil kesimpulan bahwa partisipasi publik selalunya akan memberikan lebih banyak solusi terhadap hal-hal apabila dibandingkan dengan pelayanan pablik professional pada umumnya. Karena partisipasi masyarakat dalam memberikan solusi terhadap masalah yang mereka hadapi memiliki kelebihan diantaranya: masyarakat awam memiliki komitmen yang lebih besar terhadap para anggotanya dibanding komitmen para penyelenggara Negara. Masyarakat awam lebih baik dalam memahami masalahnya sendiri apabila dibandingkan dengan para professional penyedia layanan; para professional dan pegawai pemerintahan memberikan layanan sedangkan maasyarakat awam menyelesaikan berbagai permasalahan; para professional dan pegawai pemerintahan menawarkan pelayanan sedangkan masayarakat awam memberikan kepedulian; masyarakat awam berusaha menegakkan standart perilaku dengan efektif disbanding denganm para professional pelayan dan pegawai pemerintahan. 
didasarkan akan perlunya usaha untuk memperbaiki lingkungan sosial yang pada akhirnnya akan dinikmati secara bersama. Sedangkan pola pendekatan kemasyarakatan dapat dilakukan melalui pemberdayaan kapasitas masyarakat untuk mendorong pemanfaatan nilai-nilai sosial budaya yang dimiliki sebagai suatu modal sosial (sosial capital) dalam pembangunan berkelanjutan.

$$
\text { Pada dasarnya pemberdayaan }
$$

masyarakat lokal dalam proses pembangunan di suatu negara adalah bentuk usaha usaha terencana untuk memberikan kewenangan kepada masyarakat untuk ikut berperan aktif dalam merencanakan apa sesungguhnya yang mereka sangat perlukan, dan mereka yang akan melaksanakan sendiri, mengawasi dan memanfaatkan sendiri. Pada akhirnya akan berujung pada transformasi sosial yang yang sesuai dengan kapasitas yang mereka miliki, selain juga pemberdayaan masyarakat lokal sebagai wujud untuk memberikan keleluasaan kepada masyarakat supaya masyarakat pada tingkat lokal dapat menentukan pilihan dan memberikan respons terhadap perubahan sosial sehingga perubahan sosial mampu memberikan makna sesuai dengan apa yang mereka kehendaki. Pelibatan partisipasi masyarakat dalam berbagai aspek pembangunan haruslah didasari dengan prinsip saling memerlukan dan menguntungkan bagi masyarakat dan negara dengan pandangan yang setara (equal) baik dalam struktur mapun dalam tanggungjawab. ${ }^{21}$

$$
\text { Pada sisi lain dalam konteks }
$$
ketatanegaraan, keberadaan pemerintah dalam kehidupan masyarakat tidak dapat diabaikan, karena pada dasarnya kehadiran pemerintah adalah untuk mengatur dan melindungi masyarakat supaya senatiasa dalam keadaan aman dan tertib, yang dalam teori pemerintahan fungsi utama pemerintah itu adalah perwujudan "regulation and service". Akan

$$
{ }^{21} \text { Ibid. }
$$

tetapi seiring dengan perkembangan zaman, bagaimanapun kuatnya kekuasaan pemerinntah diyakini tidak akan mampu menyelenggarakan pemerintahan secara terpusat secara berkelanjutan, maka ide desentralisasi menjadi suatu yang sangat diperlukan dalam pembangunan suatu negara, terlebih pembangunan negara dengan konsep demokratisasi. Karena desentralisasi menghendaki pelimpahan kewenangan dan tanggungjawab dari pusat kekuasaan kepada daerah, ini berarti bahwa peluang pemberdayaan nilai-nilai lokal sangatlah terbuka, sehingga masyarakat dapat tumbuh dan berkembang sesuai dengan nilai-nilai lokal, karena diyakini nilai-nilai kearifan lokal masyarakat (local wisdom).

\section{REFORMASI PEMERINTAHAN MANAJEMEN SEBAGAI \\ LANGKAH AWAL DEMOKRATISASI}

Reformasi manajemen pemerintahan merupakan aspek yang sangat penting dalam pertumbuhan di negara-negara berkembang. Keutamaan perkembangan atau kecepatan pertumbuhan dan arah pengembangan negara sangat pantas dan berubah. Menurut Ceid ${ }^{22}$ lahirnya kepentingan akan reformasi manajemen pemerintahan disebabkan perubahan sistem manajemen pemerintahan yang dikaitkan dengan usaha meningkatkan kemampuan dan keprofesionalan organisasi.

Lee $^{23}$ memperkenalkan pola kegiatan manajemen pemerintahan di beberapa negara, reformasi manajemen pemerintahan diperkenalkan karena terdapat perubahan sistem politik seperti di Brazil, Ghana dan Tanzania. Tindakan - tindakan yang terencana di bidang manajemen pemerintahan mengakibatkan perubahan yang berarti dalam

22 G.E. Ceiden, Administrative Reform, In farazmand, Handbook of Comparative and Development Administration, (New York: Mercel Deccer Inc., 1992). 25.

${ }^{23}$ Ibid. 4 
diri aparatur pemerintah. Reformasi manajemen pemerintah dibanyak negara berkembang memperlihatkan peranan organisasi antara bangsa dan pemerintahan negara asing sangat aktif untuk melakukan perbaikan manajemen pemerintahan melalui bantuan teknis.

Pengalaman pelaksanaan reformasi sistem manajemen pemerintahan di negaranegara tersebut melahirkan banyak model. Dalam hubungan ini Zauhar ${ }^{24}$ melihat bahwa reformasi manajemen pemerintahan merupakan suatu pola yang menunjukkan peningkatan pemanfaatan sumber daya yang tersedia untuk mencapai tujuan yang telah ditetapkan. Dengan demikian dalam reformasi manajemen pemerintahan lebih dicurahkan pada usaha dan bukan semata-mata hasil. Secara internal tujuan reformasi adalah untuk menyempurnakan dan meningkatkan aktivitas pelayanan publik secara sempurna.

Riggs ${ }^{25}$ melihat reformasi atau pembaharuan pada dua sisi yaitu perubahan struktur dan manajemen. Secara struktural adanya penggunaan perubahan susunan sebagai salah satu ukuran. Pandangan ini didasarkan pada arah peranan-peranan yang semakin terkhususkan dan pembagian kerja yang semakin jelas dan terarah dalam masyarakat modern. $\mathrm{Katz}^{26}$ melakukan analisis yang lebih mutahir mengenai keadaan sistem manajemen pemerintahan di negara berkembang dan mengungkapkan bahwa upaya memperbaiki kinerja birokrasi pemerintah mesti meliputi tanggapan sumber daya dan kualitas pelayanan.

24 Soesilo Zauhar, Desentralisasi Dan Otonomi Daerah Dan Pembangunan Nasional (Jakarta: Pelopor, 1994). 4

${ }^{25}$ F.W. Riggs, Administrasi Pembangunan, (Jakarta: Rajawali, 1996), 94

26 Sm Katz, Modernisasi Administrasi dan Pembangunan Nasional, (Jakarta: Bumi Aksara, 1987), 87.

\section{MANAJEMEN PEMERINTAHAN BERBASIS BUDAYA LOKAL}

Kontroversi pemberdayaan budaya lokal dalam sistem manajemen pemerintahan telah terjadi sejak lama, bahkan sejak zaman kolonial Belanda dahulu. Hal ini dikarenakan keberadaan pemerintahan selalu ada pada dua sisi yaitu pada sisi pelayanan publik, tetapi juga pelayan kekuasaan. Keadaan yang berbeda ini memerlukan otonomi relatif, osisi relatif berjarak terhadap masyarakatnya dan bahkan selalu diperlukan kemampuan menerapkan hukuman-hukuman tertentu.

Tetapi pada sisi lainnya demi menjamin kekekukuhan, dukungan keabsahan, turut ambil bagian, memperoleh tanggapan dan memelihara keberlangsungan (sustainability) pemerintahan harus ramah, mendekatkan diri, mengikatkan diri pada budaya masyarakat lokal sehingga keberadaannya berarti dan dipercayai. Usaha mecapai kesepahaman yang adil selalu menjadi lebih sulit karena masyarakat yang berkembang semakin terbuka menerima perubahan, seperti akibat modernisasi dan industrialisasi. Dengan globalisasi informasi dan perdagangan sekarang ini tantangan terjadinya bencana budaya, geger budaya atau krisis identitas pasti terwujud. Secara teoritis banyak kajian yang menunjukkan bahwa tidak ada keberhasilan atau sukses berkelanjutan yang dapat dicapai dengan mengabaikan budaya lokal.

Seiring dengan berjalannya reformasi semangat untuk kembali menggali nilai-nilai budaya lokal semakin bergairah. Hal ini berguna untuk memberi respons berbagai peluang dan tantangan yang dihadapi. Tetapi pada sisi lain budaya lokal juga dihadapkan pada ujian untuk menunjukkan kemampuannya untuk menyesuaikan dengan kondisi global dan memberi respons kepada hal-hal yang bersifat pertumbuhan, seperti demokratisasi, hak asasi manusia, modernitas pada umumnya. 
Pemberdayaan budaya lokal dalam sistem manajemen berokrasi di Indonesia telah tumbuh seiring dengan lahirnya undangundang otonomi daerah komponen. Hubungan dengan undang-undang tersebut ialah pusat telah memberikan sebahagian kewenangan kepada daerah.

Anthony Gidden ${ }^{27}$ dalam bukunya The Third Way, menginginkan sebuah bangunan birokrasi yang lahir nantinya haruslah dalam rangka menumbuhkan Governance bukan lagi Goverment. Langkah yang dapat memasuki setelah birokrasi adalah menuju hukum yang dapat memberikan respons terhadap kepentingan masyarakt awam, dalam zaman seperti ini keberadaan people power harus diakui, negara dengan refresentasi pemerintahan harus dapat memberi respons nilai-nilai sosial masyarakat lokal yang berkembang.

Reformasi dapat membawa berkah bagi masyarakat akan tetapi sekaligus juga dapat membawa bencana dalam proses pembangunan kehidupan berbangsa dan bermasyarakat, manakala hakekat dari reformasi itu disalah artikan seperti yang selalu maknai oleh sebahagian masyarakat awam yang memaknai reformasi sebagai "kebebasan dan hak asasi manusia tanpa batas hukum". Sesungguhnya otonomi daerah merupakan suatu proses perubahan karena diharapkan penglibatan masyarakat dalam berbagai proses pemerintahan dapat menumbuhkan suburkan nilai demokrasi, dimana sistem birokrasi pemerintahan akan lebih sempurna dan tingkat kemandirian daerah lebih kukuh; prospek otonomi daerah secara teoritis mampu menjawab berbagai masalah yang intinya pada keadilan dan keberlanjutan.

Pentingnya penglibatan masyarakat dalam berbagai aspek pemerintahan merupakan asas pengembangan demokrasi,

${ }^{27}$ Jesper Falkheimer, "Anthony Giddens and Public Relations: A Third Way Perspective," Public Relations Review 33, no. 3 (September 2007): 287-93, doi:10.1016/j.pubrev.2007.05.008. 5 dimana rakyat memiliki kedaulatan dan sumber daya alamnya, rakyat dapat menentukan wakilwakil yang akan duduk di parlemen daerah, menentukan siapa yang akan menjadi pimpinannya, menysusun dan merancang pertumbuhan lingkungan. Oleh karena itu otonomi menuntut kesiapan aparatur negara di daerah untuk mempasilitasi aspirasi dan penglibatan masyarakat dalam mewujudkan pembangunan di daerahnya. Harapan tersebut tentu juga menghadapi berbagai tantangan, misalnya sudah maraknya korupsi, kolusi dan nepotisme, ketidak siapan para aparatur pemerintahan di daerah dan budaya otoriter peninggalan zaman orde baru.

Reformasi dalam bidang birokrasi merupakan suatu wujud yang menunjukkan peningkatan efektifitas pemanfaatan sumber daya yang tersedia untuk mencapai tujuan yang direncanakan. Dengan demikian reformasi sistem birokrasi perhatian lebih difokuskan pada usaha bukan semata-mata hasil. Secara umum dalam tujuan reformasi sistem birokrasi adalah untuk menyempurnakan atau meningkatkan kinerja. Sedangkan pada sisi lain yang berhubungan dengan masyarakat adalah menyesuaikan sistem birokrasi terhadap peningkatan keperluan masyarakat. Riggs ${ }^{28}$ melihat reformasi atau pembaharuan dari dua sisi yaitu perubahan struktur dan kinerja. Sedangkan Willis ${ }^{29}$ melakulan analisis yang lebih modern mengenai keadaan sistem birokrasi di negara berkembang dan menyatakan bahwa usaha memperbaiki kinerja birokrasi pemerintahan harus meliputi ketanggapan sumber dan efektifitas pelayanan.

Reformsi sistem birokrasi merupakan suatu usaha terencana untuk perbaikan birokrasi dan perbaikan perilaku aparatur

${ }^{28}$ Riggs, Administrasi Pembangunan, 94.

29 James F Spriggs, "Explaining Federal Bureaucratic Compliance with Supreme Court Opinions," Political Research Quarterly 50, no. 3 (1997): 567-93. 
negara yang terlibat di dalamnya, Zauhar ${ }^{30}$ berpandangan bahwa dilakukannya reformasi sistem birokrasi adalah usaha untuk menyempurnakan metode dan kinerja.

Seiring dengan itu upaya pembangunan pemerintahan yang baik maka harus diberikan prioritas pada tiga dimensi yaitu dimensi politik, hukum dan dimensi birokrasi. setiap dimensi harus didekati dengan perspektif sistem yang mengharuskan terlibatnya berbagai pihak baik perencana maupun pelaksananya. Dimensi politik ditentukan dari tingkat penerimaan masyarakat awam terhadap pemerintah, dimensi hukum berkaitan dengan adanya jaminan kepastin hukum oleh pemerintah terhadap rakyat, sedangkan dimensi birokrasi diukur dari kemampuan dan efektifitas negara memberikan pelayanan publik dan kemampuan negara memberdayakan masyarakat dalam berbagai aspek pemerintahan.

Untuk memaksimalkan cita-cita otonomi daerah, maka perubahan sistem birokrasi publik sudah seharusnya dilakukan supaya pemerintah selalu merespons keperluan dalam masyarakat dan birokrasi publik menata kembali kehidupan masyarakat. Prasyarat untuk itu semua harus dilakukan reformasi sistem birokrasi publik oleh karena pemerintahan daerah harus semakin terbuka dalam berbagai aspek kepentingan publik dalam usaha untuk mewujudkan sistem pemerintahan yang demokratis.

\section{KESIMPULAN}

Indosensia sebagai sebuah negara hukum sebagaimana yang dinyatakan dalam Pasal 1 ayat (1) Undang-Undang Dasar 1945 dengan penjelasan Recht staat not macht staat" Negara hukum bukan Negara kekuasaan belaka, untuk merealisasikan konsep negara hukum tersebut tidak ada pilihan lain lagi kecuali harus membangun demokratisasi, suatu negara hukum tidak mungkin akan terwujud manakala dinegara tersebut tidak ada demokrasi ,karena antara negara hukum dengan demokrasi ibarat dua sisi mata uang yang antara satu dengan lainnya tidak bisa dipisahkan.

Pada sisi lain sebagaimana dikatakan di atas bahwa demokrasi itu bukan sesuatu yang “ diterjunkan" dari atas akan tetapi susuatu yang dilahirkan dari bawah, sehingga proses dempkratisasi disuatu negara diyakini akan mudaha terwujud manakala negara secara sadar memberikan kebebasan dan ruang untuk merespon semaksimal mungkin nilainilai masyarakat lokal. Terlebih lagi masyarakat Indonesia yang terdiri dari berbagai macam suku, budaya dan Bahasa (multikulturalisme) yang diyakini sebagai suatu modal sosial (capital social) dalam pembangunan dalam berbagai bidang.

Penglibatan nilai-nilai budaya lokal secara prororsional dalam pembangunan akan melahirkan rasa memiliki dan bertanggungjawab yang tinggi bagi masyarakat local yang seiring daripada itu perwujudan prinsip demokrasi juga berjalan.

30 Zauhar, dalam Rakhmad MS. Reformasi Administrasi Publik Menuju Pemerintahan Daerah Yang demokratis, (Makalah Seminar, 1996). 5. 


\section{DAFTAR KEPUSTAKAAN}

Amanulloh, Naeni. "Demokratisasi Desa:" In Kementerian Desa, Pembangunan Daerah Tertinggal, Dan Transmigrasi Republik Indonesia, 3 ed., 1-47. Jakarta, 2015.

Bryant \& Louise G White, dalam Manajemen Pembangunan untuk negara berkembang, diterjemahkan oleh Rusyanto L Simatupang, Jakarta: LP3ES, 1987.

Diamond, Larry. "Rethinking civil society: Toward democratic consolidation." Journal of democracy 5, no. 3 (1994): 4-17.

David Osborne and Ted Gaebler (1992) Reinventing Government,how the Entrepreneurial spirit is Transforming the public sector (New York: A William Patrict Book).

Falkheimer, Jesper. "Anthony Giddens and public relations: A third way perspective." Public Relations Review 33, no. 3 (1 September 2007): 287-93. doi:10.1016/j.pubrev.2007.05.008.

Feu, Jordi, Carles Serra, Joan Canimas, Laura Làzaro, dan Núria Simó-Gil. "Democracy and Education: A Theoretical Proposal for the Analysis of Democratic Practices in Schools." Studies in Philosophy and Education 36, no. 6 (2017): 647-61. doi:10.1007/s11217-017-95707.

F.W.Riggs, Administrasi Pembangunan, Jakarta: Rajawali, 1996.

Gainous, Jason, Jason P. Abbott, dan Kevin M. Wagner. "Traditional Versus Internet Media in a

Restricted Information Environment: How Trust in the Medium Matters." Political Behavior 41, no. 2 (2019): 401-22. doi:10.1007/s11109-018-9456-6.

G.E. Ceiden, Administrative Reform, In farazmand, Handbook of Comparative and Development Administration, New York: Mercel deccer, Inc., 1992.

James Midgley, Community Partisipation, Social Develpoment and the State, London, 1996.

Hidayat, Komaruddin \& Azyumardi Azra, Demokrasi, Hak Azazi Manusia, Dan Masyarakat Madani, Jakarta: ICCE UIN Syarif Hidyatullah, 2006.

Methium, Sm Katz, Modernisasi Administrasi dan Pembangunan Nasional, Jakarta: Bumi Aksara, 1987.

Nugroho, Heru. "Demokrasi dan Demokratisasi: Sebuah Kerangka Konseptual Untuk Memahami Dinamika Sosial-Politik di Indonesia." Jurnal Pemikiran Sosiologi 1, no. 1 (14 Desember 2015): 1. doi:10.22146/jps.v1i1.23419.

Riggs F.W., Administrasi Pembangunan, Jakarta: Rajawali, 1996.

Sangian, Daniel A., Salmin Dengo, dan Jericho D. Pombengi. "Summary for Policymakers." In Climate Change 2013 - The Physical Science Basis, diedit oleh Intergovernmental Panel on Climate Change, 53:1-30. Cambridge: Cambridge University Press, 2013. doi:10.1017/CBO9781107415324.004.

Schneider, Ingrid. "Osborne, D. and Gaebler, T. 1992. Reinventing Government. New York, NY.” Journal of Leisure Research, A William Patrick Book, 27, no. 3 (13 September 1995): 3024. doi:10.1080/00222216.1995.11949751.

Spriggs, James F. "Explaining federal bureaucratic compliance with Supreme Court opinions." Political Research Quarterly 50, no. 3 (1997): 567-93.

Willis M., Bureucracy, London: Mc. Millan, 1989.

Zauhar, Soesilo. Desentralisasi dan Otonomi Daerab dan Pembangunan Nasional. Jakarta: Pelopor, 1994. 